\title{
Richness and diversity of odonates of the agricultural college and research institute, Vazhavachanur, Tamilnadu, India
}

\author{
VAITHIYANATHAN RADHAKRISHNAN, ${ }^{1}$ RAMANATHAN ARULPRAKASH, ${ }^{2}$ \\ IYAPPAN PARIVARTHANI, ${ }^{3}$ SELVARASU PONNIVALAVAN, ${ }^{3}$ \\ MOHAN PRIYADHARSHINI, ${ }^{3}$ MUTHAIYAN PANDIYAN ${ }^{4}$ \\ Agricultural College and Research Institute, Vazhavachanur - 606 753, Thiruvannamalai District, Tamil Nadu, India \\ 2 Seeds Centre, Tamil Nadu Agricultural University, Coimbatore - 641 003, Tamil Nadu, India \\ Agricultural College and Research Institute, Vazhavachanur - 606 753, Thiruvannamalai District, Tamil Nadu, India \\ ${ }^{4}$ Agricultural College and Research Institute, Vazhavachanur - 606 753, Thiruvannamalai District, Tamil Nadu, India \\ Corresponding Authoraｅ-mail:drvradhakrishnan@gmail.com,mpandiyan8@yahoo.in
}

Keywords Vazhavachanur, Dragonfly, Damselfy, Libellulidae and Coenagrionidae

Abstract Investigations on the diversity of Odonata in and around the Agricultural College and Research Institute, Vazhavachanur, Tamil Nadu, India were studied. Eight locations were selected, of which sixteen Odonata species were recorded. In total, eleven dragonfly and five damselfly species were identified from Thiruvannamalai district, Tamil Nadu, India. Pantala flavescens, Diplacodes trivialis, Brachythemis contaminata and Ischnura aurora were recorded from all eight locations. Trithemis pallidinervis and Agriocnemis pygmaea were recorded from seven locations except from the farm pond and the open stretch area. Rhyothemis variegata was recorded only at the open stretch area. The results clearly show that, Odonates have specific habitat preferences for their growth and development. Four families Libellulidae, Gomphidae, Aeshnidae and Coenagrionidae were observed and collected during the study. Libellulidae were the most abundant family (56.25\%) and comprised of 9 species, followed by Coenagrionidae $(31.25 \%)$ with 5 species. Low species abundance was recorded within the Gomphidae and Aeshnidae families with $6.25 \%$ each. Simpson and Shannon Index showed maximum diversity in the open stretch area ( 0.8743 and 2.186 , respectively) and minimum in location 8 (crop production area) and location 4 (Sathakuppam), respectively. Open stretch area showed maximum Richness Index (Margalef) (2.275) followed by farm pond (2.196) where recorded minimum in sathakuppam (1.276) location. Equitability J index, maximum species evenness $(0.788)$ was recorded Location 6 i.e. farm pond $(0.6727)$ followed by open stretch area 0.686 .

\section{Bogactwo i różnorodność ważek z terenu kolegium rolniczego i instytutu badawczego, Vazhavachanur, Tamilnadu, Indie}

Słowa kluczowe Vazhavachanur, ważki różnoskrzydłe, ważki równoskrzydłe, Libellulidae i Coenagrionidae

Streszczenie Zbadano różnorodność Odonata w Kolegium Rolniczym i Instytucie Badawczym w Vazhavachanur, Tamil Nadu w Indiach i wokół niego. Wybrano osiem lokalizacji, gdzie 
odnotowano 16 gatunków Odonata. Łącznie w okręgu Thiruvannamalai w stanie Tamil Nadu w Indiach zidentyfikowano 11 gatunków ważek różnoskrzydłe i 5 gatunków ważek równoskrzydłych. Pantala flavescens, Diplacodes tryialis, Brachythemis contaminata i Ischnura aurora odnotowano we wszystkich ośmiu lokalizacjach. Trithemis pallidinervis i Agriocnemis pygmaea odnotowano w siedmiu miejscach, z wyjątkiem stawu hodowlanego i otwartego obszaru. Rhyothemis variegata odnotowano tylko na otwartym terenie. Wyniki wyraźnie pokazują, że ważki mają określone preferencje siedliskowe dotyczące ich wzrostu i rozwoju. Podczas badań zaobserwowano i zebrano cztery rodziny: Libellulidae, Gomphidae, Aeshnidae i Coenagrionidae. Najliczniejszą rodziną były Libellulidae (56,25\%), składające się z 9 gatunków, następnie Coenagrionidae (31,25\%) z 5 gatunkami. Niską liczebność gatunków odnotowano w rodzinach Gomphidae i Aeshnidae po 6,25\%. Indeks Simpsona i Shannona wykazał maksymalne zróżnicowanie na otwartym obszarze (odpowiednio 0,8743 i 2,186) i minimalne w lokalizacji 8 (obszar upraw) i lokalizacji 4 (Sathakuppam). Otwarty obszar wykazywał maksymalny wskaźnik bogactwa (Margalef) $(2,275)$, następnie był staw hodowlany $(2,196)$, minimalny wskaźnik bogactwa odnotowano w lokalizacji Sathakuppam $(1,276)$. Wskaźnik równości J, maksymalna równość gatunkowa $(0,788)$ odnotowano w lokalizacji 6 , tj. Staw hodowlany $(0,6727)$, a następnie na otwarty obszarze $(0,686)$.

\section{Introduction}

Odonataare an important predatory order which includes Dragonflies (Anisoptera) and Damselflies (Zygoptera). The odonate larvae are in aquatic habitat and the adults are excellent aerial predators. The insect possess large compound eye which helps to capture the prey comfortably. Of which, dragonflies are performing strong flying activity under the suborder called Anizoptera and damselflies are weak flier under the suborder of Zygoptera (Tofilski, 2004). The insects distributed almost throughout the world (Tillyard, 1917). Selvarasu et al. (2019), reported that it is the second largest aquatic insect order in the animal kingdom. Chovanec and Waringer (2001) reported that Odonates are so sensitive and it will react immediately even small fraction of changes in the habitation. Rowe (2003) reported that, the odonates nymph indirectly helps to control the epidemic diseases of human beings viz., malaria, dengue, filaria, since, the mosquito larvae are aquatic and it will be of good source of food for odonates nymphs. It prefers live fresh water, non-polluted and oxygenated habitats (Manwar et al., 2014). Nesemann et al. (2011) reported that, odonates are playing an important role in climate change mainly due to evolutionary history and its adaptations.

In India, 474 species and 50 subspecies which belongs to 142 genera and 18 families were recorded. Seventeen Odonates species recorded from Howrah district, West Bengal (Dwari, Mondal, 2017) and 36 species from Meghalaya (Acharjee, Karzee, 2016) in India. The Odonates diversity have been studied in all the agro-ecosystems, wherein 31 species were recorded in Amravathi city, Maharashtra (Rathod et al., 2012)

Many studies were carried out on Odonates diversity different parts of Tamil Nadu, viz., 16 species in rice field from Coimbatore district (Gunathilagaraj et al., 1999), 21 species from Coimbatore and Salem district (Arulprakash, Gunathilagaraj, 2010), 29 species from Kanyakumari district (Elanchezhyan et al., 2017) and 8 species were recorded in Mangroove forest (Muthukumaravel et al., 2015). Odonata diversity is lacking in Thiruvannamalai district, Tamil Nadu and hence, the present study have been undertaken forthe taxonomic identification, richness and abundance. 


\section{Materials and methods}

The present study was undertaken in and around Agricultural College and Research Institute, Vazhavachanur, Thiruvannamalai, Tamil Nadu. Annual rainfall of Thiruvannamalai district is $1074.70 \mathrm{~mm}$, the average annual temperature is $28.3^{\circ} \mathrm{C}$ and it comes under the tropical climate. Thiruvannamalai gets more rainfall during the summer season than winter season. Nearly $45 \%$ of the rainfall is received during north east monsoon period (October-December). The sources of water is Sathanur Dam, wells and in some cases bore wells. Most commonly available tree species in our collection premises are Neem, Vaagai, Silk cotton, Tamarind tree, Banyan tree, Peepal tree, Prosopis, etc. and common weed species are Cyperus, Lantana, Parthenium, Chaff flower, swollen finger grass, wire weed, Crab grass, Corchorus etc.

\section{Wet land ecosystem}

It is distinct ecosystem which is inundated by water either permanently or seasonally. In the present study, the paddy crop was used for collection of odonates to study the abundance and species richness. Six different paddy field were selected to observe the abundance of odonates. Each paddy field showed different growth phases and the bunds also were smothered with vigorous weed growth.

\section{Pond (Stagnated water)}

To study the Odonata diversity the College farm pond was selected where human inferences is very minimum. The Farm pond gets filled with water during January to March whenever there is flow of water from the canal present near the college boundary. The water will be available for few months and gets dried up during summer.

\section{River canal}

It is located adjacent to Thenpennai river for irrigation of farmer field and it is near to campus.

\section{Open land stretch}

Barren land were selected to study the diversity.

\section{Geographical information's}

Table 1. Geographical information of the different locations

\begin{tabular}{|l|c|c|c|c|c|c|}
\hline \multicolumn{1}{|c|}{ Location details } & $\begin{array}{c}\text { Latitude } \\
(\mathrm{n})\end{array}$ & $\begin{array}{c}\text { Longitude } \\
(\mathrm{e})\end{array}$ & $\begin{array}{c}\text { Altitude } \\
(\mathrm{m})\end{array}$ & Crop & Aquatic status & $\begin{array}{c}\text { Shade } \\
\text { cover }\end{array}$ \\
\hline Seed farm 1 & $12^{\circ} 4^{\prime} 37^{\prime \prime}$ & $78^{\circ} 58^{\prime} 60^{\prime \prime}$ & 153.98 & Paddy & Seasonal aquatic & Partial \\
\hline (Paddy field) Near college gate & $12^{\circ} 4^{\prime} 18^{\prime \prime}$ & $78^{\circ} 59^{\prime} 8^{\prime \prime}$ & 158.98 & Paddy & Seasonal aquatic & Partial \\
\hline Seed farm 2 & $12^{\circ} 4^{\prime} 28^{\prime \prime}$ & $78^{\circ} 59^{\prime} 59^{\prime \prime}$ & 149.98 & Paddy & Seasonal aquatic & Partial \\
\hline Sathakuppam & $12^{\circ} 4^{\prime} 18^{\prime \prime}$ & $78^{\circ} 58^{\prime} 41^{\prime \prime}$ & 148.98 & Paddy & Seasonal aquatic & No \\
\hline Open stretch area & $12^{\circ} 4^{\prime} 33^{\prime \prime}$ & $78^{\circ} 59^{\prime} 0^{\prime \prime}$ & 156.98 & - & Seasonal aquatic & Partial \\
\hline Farm pond & $12^{\circ} 4^{\prime} 33^{\prime \prime}$ & $78^{\circ} 59^{\prime} 6^{\prime \prime}$ & 165.98 & - & Temporary & Partial \\
\hline Seed farm 3 & $12^{\circ} 4^{\prime} 39^{\prime}$ & $78^{\circ} 58^{\prime} 83^{\prime \prime}$ & 164.65 & Paddy & Seasonal aquatic & Partial \\
\hline Crop production area & $12^{\circ} 4^{\prime} 22^{\prime \prime}$ & $78^{\circ} 59^{\prime} 12^{\prime \prime}$ & 141.98 & Paddy & Seasonal aquatic & No \\
\hline
\end{tabular}




\section{Survey and collection of Odonates}

Odonata specimens were collected through direct survey from various locations in and around the Agricultural college campus. The areas surveyed are presented in Plate 1, 2 and 2a. Collections were done by different methods viz., zigzag collection, visual observation were also done. Zigzag method is used to collect odonates by using aerial net along with walk. Transect or zigzag walk conducted to cover the selected areas. This method has been widely used for quantitative sampling encountered while visual survey along transects is used for abundance of insect species. The total number of individuals in each species encountered during six months of sampling period (December 2018 to April 2019) is used for comparing their abundance and diversity.

The collection of insects were done by using a long-handled aerial net. A net opening of at least $30 \mathrm{~cm}$ diameter makes the job easier. Some collectors feel that a dark net bag (black or green) is less conspicuous to dragonflies and thus is more effective than a white one. Observing patrolling dragonflies before swinging at them often pays off; positioning yourself in the most advantageous location, especially if it is somewhat concealed, is usually fruitful. When attempting to a dragonfly, move deliberately. Refrain from waving the net around; keep it as inconspicuous as possible. Swing at fast-flying agile species from behind as they fly by; many will easily dodge a net swung head-on. Collected insects were anaesthetized and preserved properly for further studies.

The collected odonates were photographed for the species identification. Odonate richness, abundance and diversity (Ludwig, Reynolds, 1998) was calculated by using the software 'Biodiversity Calculator':http://www.alyoung.com/labs/biodiversity_calculator.html.

\section{Results}

A total of 16 odonates species representing 4 families viz., Libellulidae (9), Gomphidae (1), Aeshinidae (1) and Coenagrionidae (5) were observed and taxonomic studies were studied. The detailed taxonomic identification from genera, species, family level have been identified.

\section{Diversity of Odonata}

Out of 11 dragonfly species, Pantala flavescens were observed from paddy field and Open stretch area and recorded more population (303 ind.) followed by Diplacodes trivialis (195 ind.) observed from farm pond and least populations were recorded from Anax sp. (2 ind.) were observed from open stretch area (Table 2).

Table 2. Diversity of odonata in \& around ac\&ri, Vazhavachanur from December to April

\begin{tabular}{|c|l|c|c|c|c|}
\hline No. & \multicolumn{1}{|c|}{ Common name } & Scientific Name & Family & Habitat & $\begin{array}{c}\text { Abundance } \\
\text { (Nos.) }\end{array}$ \\
\hline \multicolumn{5}{|c|}{ Dragonfly } \\
\hline 1. & Wandering glider & $\begin{array}{c}\text { Pantala flavascens } \\
\text { (Fabricius, 1798) }\end{array}$ & Libellulidae & $\begin{array}{c}\text { Paddy field } \\
\text { \& Open stretch area }\end{array}$ & 303 \\
\hline 2. & Chalky percher & $\begin{array}{c}\text { Diplocodes trivialis } \\
\text { (Rambur, 1842) }\end{array}$ & Libellulidae & Farm pond & 195 \\
\hline 3. & Ditch jewel & $\begin{array}{c}\text { Brachythemis contaminata } \\
\text { (Fabricius,1793) }\end{array}$ & Libellulidae & $\begin{array}{c}\text { Paddy field } \\
\text { \& Open stretch area }\end{array}$ & 98 \\
\hline 4. & $\begin{array}{l}\text { Coral- tailed } \\
\text { cloud wing }\end{array}$ & $\begin{array}{c}\text { Tholymis tillarga } \\
\text { (Fabricius,1793) }\end{array}$ & Libellulidae & Farm pond & 43 \\
\hline
\end{tabular}


Richness and diversity of odonates of the agricultural college and research institute...

Continuation of Table 2

\begin{tabular}{|c|c|c|c|c|c|}
\hline 5. & $\begin{array}{l}\text { Long - legged } \\
\text { marsh glider } \\
\end{array}$ & $\begin{array}{c}\text { Trithemis pallidinervis } \\
\text { (Kirby, 1889) }\end{array}$ & Libellulidae & Paddy field & 142 \\
\hline 6. & Scarlet skimmer & $\begin{array}{l}\text { Crocothemis servilia } \\
\text { (Drury, 1770) }\end{array}$ & Libellulidae & $\begin{array}{c}\text { Paddy field } \\
\& \text { Open stretch area }\end{array}$ & 67 \\
\hline 7. & Slender skimmer & $\begin{array}{l}\text { Orthetrum sabina } \\
\text { (Drury, 1770) }\end{array}$ & Libellulidae & Open stretch area & 39 \\
\hline 8. & $\begin{array}{l}\text { Variegated } \\
\text { flutterer }\end{array}$ & $\begin{array}{l}\text { Rhyothemis variegata } \\
\text { (Linnaeus, 1763) }\end{array}$ & Libellulidae & Openstretch area & 5 \\
\hline 9. & Common club tail & $\begin{array}{l}\text { Ictinogomphus rapax } \\
\text { (Rambur, 1842) }\end{array}$ & Gomphidae & Farm pond & 9 \\
\hline 10. & - & Anox sp. & Aeshnidae & Open stretch area & 2 \\
\hline 11. & Asian pintail & $\begin{array}{c}\text { Acisoma panorpoides } \\
\text { (Rambur, 1842) }\end{array}$ & Libellulidae & Open stretch area & 8 \\
\hline \multicolumn{6}{|c|}{ Damselfly } \\
\hline 1. & Yellow wax tail & $\begin{array}{l}\text { Ceriagrion coromandelium } \\
\text { (Fabricius, 1798) }\end{array}$ & Coenagrionidae & $\begin{array}{l}\text { Paddy field } \\
\& \text { Farm pond }\end{array}$ & 41 \\
\hline 2. & Blue river damsel & $\begin{array}{c}\text { Pseudagrion } \\
\text { microcephalum } \\
\text { (Rambur, 1842) }\end{array}$ & Coenagrionidae & Farm pond & 51 \\
\hline 3. & Golden darlet & $\begin{array}{l}\text { Ischnura aurora } \\
\text { (Brauer, 1865) }\end{array}$ & Coenagrionidae & Paddy field & 502 \\
\hline 4. & Wandering midget & $\begin{array}{l}\text { Agriocnemis pygmaea } \\
\text { (Rambur, 1842) }\end{array}$ & Coenagrionidae & Paddy field & 283 \\
\hline 5. & Marsh blue tail & $\begin{array}{l}\text { Ischnura senegalensis } \\
\text { (Rambur, 1842) }\end{array}$ & Coenagrionidae & Farm pond & 32 \\
\hline \multicolumn{5}{|c|}{ Total } & 1,820 \\
\hline
\end{tabular}

\begin{tabular}{|c|c|c|c|c|c|c|c|c|}
\hline Details & Loc 1 & Loc 2 & Loc 3 & Loc 4 & Loc 5 & Loc 6 & Loc 7 & Loc 8 \\
\hline \multicolumn{9}{|c|}{ Dragonfly } \\
\hline Pantala flavescens & $\checkmark$ & $\checkmark$ & $\checkmark$ & $\checkmark$ & $\checkmark$ & $\checkmark$ & $\checkmark$ & $\checkmark$ \\
\hline Diplocodes trivialis & $\checkmark$ & $\checkmark$ & $\checkmark$ & $\checkmark$ & $\checkmark$ & $\checkmark$ & $\checkmark$ & $\checkmark$ \\
\hline Brachythemis contaminata & $\checkmark$ & $\checkmark$ & $\checkmark$ & $\checkmark$ & $\checkmark$ & $\checkmark$ & $\checkmark$ & $\checkmark$ \\
\hline Tholymis tillarga & - & - & - & - & - & $\checkmark$ & - & - \\
\hline Trithemis pallidinervis & $\checkmark$ & $\checkmark$ & $\checkmark$ & $\checkmark$ & $\checkmark$ & - & $\checkmark$ & $\checkmark$ \\
\hline Crocothemis servilia & $\checkmark$ & $\checkmark$ & $\checkmark$ & - & $\checkmark$ & $\checkmark$ & $\checkmark$ & - \\
\hline Orthetrum sabina & $\checkmark$ & $\checkmark$ & $\checkmark$ & $\checkmark$ & $\checkmark$ & $\checkmark$ & $\checkmark$ & - \\
\hline Rhyothemis variegata & - & - & - & - & $\checkmark$ & - & - & - \\
\hline Ictinogomphus rapax & - & - & - & - & $\checkmark$ & $\checkmark$ & - & - \\
\hline Anax sp. & - & - & - & - & $\checkmark$ & - & - & - \\
\hline Acisoma panorpoides & - & - & - & - & $\checkmark$ & $\checkmark$ & - & - \\
\hline \multicolumn{9}{|c|}{ Damselfly } \\
\hline Ceriagrion coromandelium & - & - & $\checkmark$ & - & $\checkmark$ & $\checkmark$ & - & - \\
\hline Pseudoagrion microcephalum & - & - & - & - & $\checkmark$ & $\checkmark$ & - & - \\
\hline Ishnura aurora & $\checkmark$ & $\checkmark$ & $\checkmark$ & $\checkmark$ & $\checkmark$ & $\checkmark$ & $\checkmark$ & $\checkmark$ \\
\hline Agriocnemis pygmaea & $\checkmark$ & $\checkmark$ & $\checkmark$ & $\checkmark$ & $\checkmark$ & $\checkmark$ & $\checkmark$ & $\checkmark$ \\
\hline Ishnura senegalensis & - & - & - & - & $\checkmark$ & $\checkmark$ & - & - \\
\hline
\end{tabular}


Out of 5 damselfly species, Ischnura aurora (502 ind.) dominated in and around the AC\&RI, Vazhavachanur campus which was recorded from paddy field followed by Agriocnemis pygmaea (283 ind.) also recorded from Paddy field and Ischnura senegalensis (32 ind.) recorded very less population from farm pond in our campus.

\section{Diversity of Odonata in different locations}

The dragonflies, Pantala flavescens, Diplacodes trivialis and Brachythemis contaminata and damselflyspecies, Ischnura aurora were recorded from all eight location (Table 3).

Table 3. Diversity of Odonata in different locations

\begin{tabular}{|l|l|}
\hline Loc 1: Seed farm 1 & Loc 5: Open stretch land \\
\hline Loc 2: Paddy field (Near college gate) & Loc 6: Farm pond \\
\hline Loc 3: Seed farm 2 & Loc 7: Seed farm3 \\
\hline Loc 4: Sathakuppam & Loc 8: Crop production area \\
\hline
\end{tabular}

Trithemis pallidinervis and Agriocnemis pygmaea recorded seven locations except farm pond and open stretch area. Whereas, Rhyothemis variegata recorded only one location i.e., open stretch area. The results clearly shows that, Odonates have specific habitat for its growth and development.

\section{Odonata diversity in different family level}

Representatives of four families viz., Libellulidae, Gomphidae, Aeshnidae and Coenagrionidae were observed and collected during the study. Out of four families, Libellulidae occupies maximum abundance $(56.25 \%$ ) which comprises of 9 dragonfly species, followed by Coenagrionidae $(31.25 \%)$ occupies 5 damselfly species and minimum of Gomphidae and Aeshnidae recorded $6.25 \%$ and $6.25 \%$, respectively (Figure 1 ).

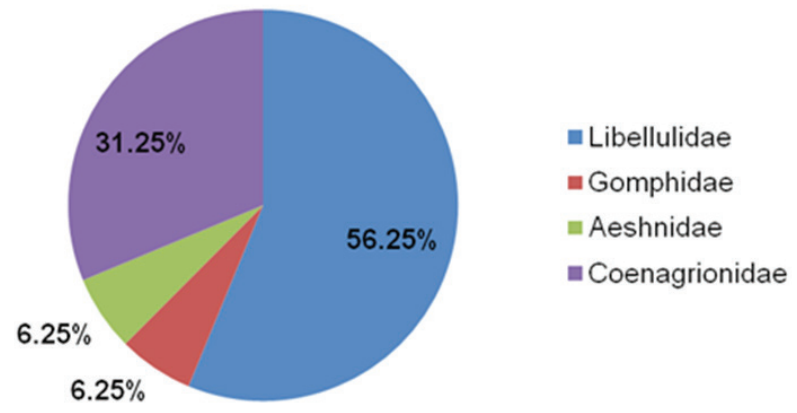

Figure 1. Abundance of Odonata in different families

\section{Abundance and Diversity of Odonata}

Simpsonand Shannon Index showed maximum diversity in the open stretch area $(0.8743$ and 2.186, respectively) and minimum in location 8 (crop production area) and location 4 (Sathakuppam), respectively (Table 4). Open stretch area showed maximum Richness Index 
(Margalef) (2.275) followed by farm pond (2.196) where recorded minimum in Sathakuppam (1.276) location. Equitability J index, maximum species evenness $(0.788)$ was recorded Location 6 i.e. farm pond $(0.6727)$ followed by open stretch area 0.686 .

Table 4. Abundance and diversity of Odonata

\begin{tabular}{|l|c|c|c|c|}
\hline \multicolumn{1}{|c|}{ Location } & $\begin{array}{c}\text { Simpson } \\
\text { dominance index }\end{array}$ & Shannon index & $\begin{array}{c}\text { Margalef richness } \\
\text { index }\end{array}$ & Evenness \\
\hline Location 1 & 0.6777 & 1.391 & 1.427 & 0.502 \\
\hline Location 2 & 0.7996 & 1.691 & 1.665 & 0.609 \\
\hline Location 3 & 0.8176 & 1.766 & 1.831 & 0.637 \\
\hline Location 4 & 0.6015 & 1.242 & 1.276 & 0.448 \\
\hline Location 5 & 0.8103 & 1.904 & 2.275 & 0.686 \\
\hline Location 6 & 0.8743 & 2.186 & 2.196 & 0.788 \\
\hline Location 7 & 0.8165 & 1.752 & 1.659 & 0.632 \\
\hline Location 8 & 0.6727 & 1.281 & 1.385 & 0.462 \\
\hline
\end{tabular}

Loc 1: Seed farm 1.

Loc 5: Open stretch land.

Loc 2: Paddy field (Near college gate).

Loc 3: Seed farm 2.

Loc 6: Farm pond.

Loc 7: Seed farm 3.

Loc 4: Sathakuppam.

Loc 8: Crop production area.

\section{Discussion}

Odonates are extremely susceptible to the insecticides and the number of doses will be increased in the rice filed, the abundance also reduced (Smith, Straton, 1986; Tang, Siegfried, 1995).

The odonata family Libellulidae was the widespread species and this was in accordance with the result of Shelton and Edwards (1983). In our study also, the Libellulidae family accounts $56.25 \%$ besides four families. It clearly shows that, this family is one of the most prevalent one all over the globe. Biotic and abiotic factors straightly affect the odonate insect inhabitants (Kittelson 2004; Goldsmith 2007; Bispo, Oliveira 2007).

Damselfly population was recorded minimum when compare to dragonfly in this study. This is in accordance with the results of Weir (1974) who stated that less abundance is mainly due to their limited dispersal ability and Clark and Samways (1996) reported that partial/ absence of shade cover. Arulprakash and Gunathilagaraj (2010) also reported that shade over the habitat which facilitates rich abundance of damselflies. Maximum Odonates were observed and recoded from the farm pond area. This was in accordance with the studies of Baruah and Saikia (2015) i.e., water bodies will attract the insects.

Krishnasamy et al. (1984), Asaithambi and Manikavasagam (2002) and Bhatacharya et al. (2006) reported that Diplacodes trivialis, Pantala flavescens, Orthetrum sabina (Anisoptera), Ischnura aurora and Agriocnemispygmaea (Zygoptera) were the dominant species and observed from transplanting to harvesting stage. This was also in accordance with the present study.

Open Stretch area recorded maximum richness (2.275) followed by farm pond (2.196) in our study, where as Baruah and Saikia (2015) also reported that species richness or Margalef's richness $(\mathrm{DMg})$ index was found to be maximum in open tracts. 


\section{References}

Acharjee, B.K., Karzee, L. (2016). A checklist of dragonfly (Odonata: Anisoptera) diversity in the campus of University Of Science And Technology, Meghalaya (USTM), RiBhoi district, Meghalaya, India. Journal of Entomology and Zoology Studies, 4 (3), 124-127.

Arulprakash, R., Gunathilagaraj, K. (2010). Abundance and diversity of Odonata in temporary water bodies of Coimbatore and Salem districts in Tamilnadu. Journal of Threatened taxa, 2 (8), 1099-1102.

Asaithambi, M., Manickavasagam, S. (2002). Odonata of Annamalai University, Annamalai Nagar, Tamil Nadu. Zoos' Print Journal, 17, 704-706.

Baruah, C., Saikia, P.K. (2015). Abundance and Diversity of Odonates in Different Habitats of Barpeta District, Assam, India. International Research Journal of Biological Sciences, 4 (9), 17-27.

Bhattacharya, B., Basit, A., Saikia, D.K. (2006). Parasitoids and predators of rice insect pests of Jorhat district of Assam. Journal of Biological Control, 20, 37-44.

Bispo, P.C., Oliveira, L.G. (2007). Diversity and structure of Ephemeroptera, Plecoptera and Trichoptera (Insecta) assemblages from riffles in mountain streams of Central Brazil. Revista Brasileira de Zoologia, 24, 283-293.

Chovanec, A., Waringer, J. (2001). Ecological integrity of river-floodplain systems-assessment by dragonfly surveys (Insecta: Odonata). Regulated Rivers: Research \& Management, 17, 493-507.

Clark, T.E., Samways, M.J. (1996). Dragonflies (Odonata) as indicators of biotype quality in the Kruger National Park, South Africa. Journal of Applied Ecology, 33, 1001-1012.

Dwari, S., Mondal, A.K. (2017). Diversity of Odonates in agricultural fields of Howrah district, West Bengal, India. Journal of Entomology and Zoology Studies, 5 (3), 1588-1595.

Elanchezhyan, K., Sowmiya, C., Agilesh, S., Venkatesh, M. (2017). Diversity of odonates at agricultural college campus, Killikulam, Tamil Nadu, India. Journal of Entomology and Zoology Studies, 5 (5), 935-940.

Goldsmith, S. (2007). Density of longhorned beetles (Coleoptera: Cerambycidae) differs at different elevations in Hawaiian montane forest. The Southwestern Naturalist, 52, 364-370.

Gunathilagaraj, K., Soundararajan, R.P., Chitra, N., Swamiappan, M. (1999). Odonata in the Rice field of Coimbatore. Zoos' Print journal, 14 (6), 43-44.

Kiauta, B. (1983). The status of the Japanese Crocothemis servilia. (Drury) as revealed by karyotypic morphology (Anisoptera: Libellulidae). Odonatologica, 12 (4), 381-288.

Kittelson, P.M. (2004). Sources of variation in insect density on Lupinus arboreus Sims: effects of environment, source population and plant genotype. The American Midland Naturalist, 152, 323-335.

Krishnasamy, N., Chauhan, O.P. Das, R.K. (1984). Some common predators of rice insect pests in Assam. International Rice Research Newsletter, 9, 15-16.

Ludwig, J.A., Reynolds, J.F. (1998). Statistical Ecology. New York: Wiley and Sons.

Manwar, N.A., Rathod, P.P., Raja, I.A. (2014). Diversity and abundance of Dragonflies and Damselflies (Order - Odonata) of Pohara Range in Pohara - Malkhed Reserve Forest, Maharashtra (India). Paripex - Indian Journal of Research, 3 (6), 208-210.

Muthukumaravel, K., Bose Raja, R., Amsath, A., Prabakaran, R., Chezhian, Y. (2015). Seasonal variation of dragonflies diversity in Muthupet Mangrove Forest, Tamil Nadu, India. International Journal of Pure and Applied Zoology, 3 (2), 188-192.

Nair, M.V. (2011). Dragonflies and damselflies of Orissa and Eastern India. Wildlife Organization, Forest and Environmental Department, Government of Orissa. 
Nesemann, H., Shah, R.T., Shah, D.N. (2011). Key to the larval stages of common Odonata of Hindu Kush Himalaya, with short notes on habitats and ecology. Journal of threatened Taxa, 3 (9), 2045-2060.

Rathod, P.P., Manwar, N.A., Pawar, S.S., Raja, I.A. (2012). Diversity and Abundance of Dragonflies and Damselflies (Order - Odonata) in Agro Ecosystems Around the Amravati City (M.S.), India in Monsoon Season. International Journal of Advanced and Innovative Research, 1 (7), 174-182.

Rowe, R. (2003). Dragonflies: Behaviour and Ecology of Odonata. Australian Journal of Entomology, 42 (2), 210-211.

Selvarasu, P., Gunasekaran, C., Agnes Deepa, A., Mohana, P., Raj Kumar, V., Chinnaraj, P. (2019). Diversity of Odonates (Insecta: Odonata) in different habitats of Vellore district, Tamil Nadu, India in Eastern Ghats. International Journal of Recent Scientific Research, 10 (4), 2127-2130.

Shelton, M.D., Edwards, C.R. (1983). Effects of weeds on the diversity and abundance of insects in soybeans. Environmental Entomology, 12, 296-299.

Smith, T.M., Straton, W. (1986). Effect of synthetic insecticides on non- target organisms. Residue Review, 97, 93-120.

Tang, J.X., Siegfried, B.D. (1995). Comparative uptake of a pyrethroid and organophosphate insecticide by selected aquatic insects. Bulletin of Environmental Contamination and Toxicology, 55, 130-135.

Tillyard, R.J. (1917). The Biology of Dragonflies. Cambridge: Cambridge University Press.

Tofilski, A. (2004). Draw Wing, a program for numerical description of insect wings. Journal of Insect Science, 4 (17), 5.

Weir, JS. (1974). Odonata collected in and near seasonal pools in Wankie National Park, Rhodesia with notes on the physio-chemical environments in which nymphs were found. Journal of the Entomological Society of South Africa, 37, 135-145.

Cite as: Radhakrishnan, V., Arulprakash, R., Parivarthani, I., Ponnivalavan, S., Priyadharshini, M., Pandiyan, M. (2020). Richness and diversity of odonates of the agricultural college and research institute, Vazhavachanur, Tamilnadu, India. Acta Biologica, 27, 57-65. DOI: 10.18276/ab.2020.27-06. 